\title{
Alternatives to antibiotic growth promoters for weanling pigs
}

\author{
Alternativas aos antibióticos melhoradores de desempenho para leitões desmamados
}

\author{
Marconi Bonfim de Santana ${ }^{\mathrm{I}}$ Antonio Diego Brandão Melo ${ }^{\mathrm{II}}$ Daniel Ribeiro Cruz ${ }^{\mathrm{I}}$ \\ Cesar Augusto Pospissil Garbossa ${ }^{\text {III }}$ Carla de Andrade ${ }^{I I}$ Vinicius de Souza Cantarelli ${ }^{\text {II }}$ \\ Leandro Batista Costa ${ }^{I^{*}}$
}

\section{ABSTRACT}

An experiment was conducted to evaluate the addition of sodium butyrate, plant extracts and nucleotides on weanling pig performance, digestive content $\mathrm{pH}$, organ morphometry, and intestinal epithelial histology. A total of 90 piglets at 21 days of age and an average initial weight of $6.35 \pm 0.34 \mathrm{~kg}$ were used. The piglets were distributed in a randomized complete block design with five treatments, six replicates, and three animals per experimental unit. The treatments consisted of the following: Control: basal diet without antibiotic; Antibiotic: basal diet with $40 \mathrm{mg} \mathrm{kg}^{-1}$ colistin sulfate and Additive: 1000 1500 and $2000 \mathrm{mg} \mathrm{kg}^{-1}$ of a combination of sodium butyrate + plant extracts + nucleotides. The experiment lasted 35 days, at which time one animal was slaughtered to assess $\mathrm{pH}$ of the digestive contents, morphometry of the organs and histology of the intestinal epithelium. No differences were found $(P>0.05)$ in the performance, $\mathrm{pH}$ of the digestive contents, morphometry of the organs or histology of the intestinal epithelium by the analysis of orthogonal polynomials or contrasts. The combination of sodium butyrate, plant extracts and nucleotides not improved the productive characteristics of weanling pigs.

Key words: herbal extracts, nucleotides, nutrition, sodium butyrate.

\section{RESUMO}

Foi conduzido um experimento para avaliar a adição de butirato de sódio, extratos vegetais e nucleotídeos sobre desempenho, $\mathrm{pH}$ do conteúdo digestório, morfometria dos órgãos e histologia do epitélio intestinal de leitões desmamados. Foram utilizados 90 leitões, com idade média de 21 dias e peso médio inicial de $6,35 \pm 0,34 \mathrm{~kg}$. Os leitões foram distribuídos em um delineamento em blocos casualizados completos, com cinco tratamentos, seis repetições por tratamento e três animais por unidade experimental. As dietas experimentais consistiam de: Controle - dieta basal sem antibiótico; Antibiótico - dieta basal com 40mg kg-1 de sulfato de colistina; Aditivo: 1000, 1500 e 2000mg $\mathrm{kg}^{-1}$ de uma combinação de butirato de sódio + extrato vegetal + nucleotídeos. No $35^{\circ}$ dia de experimentação, foi eutanasiado um animal por gaiola (unidade experimental) para avaliar o $\mathrm{pH}$ do conteúdo digestório, morfometria de órgãos e histologia do epitélio intestinal. Não foram observadas diferenças $(P>0,05)$ para desempenho, $\mathrm{pH}$ do conteúdo digestório, morfometria de órgãos e histologia do epitélio intestinal por meio das análises de polinômios ortogonais ou mesmo pelos contrastes. A combinação de butirato de sódio, extratos vegetais e nucleotídeos não melhorou as características produtivas de leitões desmamados.

Palavras-chave: extratos vegetais, nucleotideos, nutrição, butirato de sódio.

\section{INTRODUCTION}

In intensive pig farming, the post-weaning phase is critical because the animals are predisposed to enteric problems by a variety of factors. Escherichia coli strains are responsible for diarrhea, morbidity and mortality and therefore generate the greatest economic losses in production. Traditionally, antibiotics are used in pig feed as growth promoters and for the treatment of gastrointestinal infections. However, possible bacterial cross-resistance has limited the use of the antibiotics as growth promoters and alternatives such as herbal extracts, organic acids and nucleotides (ANDRADE et al., 2011; COSTA et

IDepartamento de Ciências Agrárias e Ambientais, Universidade Estadual de Santa Cruz (UESC), Salobrinho, Ilhéus, BA, Brasil.

IEscola de Ciências Agrárias e Medicina Veterinária, Pontifícia Universidade Católica do Paraná (PUCPR), Rod. BR 376, Km 14, 83010-500, São José dos Pinhais, PR, Brasil. E-mail: batista.leandro@pucpr.br. *Corresponding author.

IIIDepartamento de Zootecnia, Universidade Federal de Lavras (UFLA), Lavras, MG, Brasil. 
al., 2011) that have shown beneficial effects for pig production (YAN et al., 2011) are been studied. Many plants have multifunctional beneficial properties due to their specific bioactive components. Most biologically active plant constituents are secondary metabolites, such as terpenoids (mono- and sesquiterpenes, steroids, etc.), phenolics (tannins), glycosides, and alkaloids (present as alcohols, aldehydes, ketones, esters, ethers, lactones, etc.) (HUYGHEBAERT et al., 2011). These herbal extracts improve feed palatability, stimulate the secretion of endogenous enzymes, enhance nutrient absorption, modulate the intestinal microbiota and improve performance (WINDISCH et al., 2008). According to LAMBERT et al. (2001), the antimicrobial activity of extracts lies in their ability to disrupt bacterial cells by altering membrane permeability.

Organic acids are widely distributed in nature as normal components of plant or animal tissues. Organic acids are also formed by microbial fermentation of carbohydrates in the intestines of pigs and other intermediary metabolic processes (COSTA et al., 2011). The sodium butyrate $\left(\mathrm{C}_{4} \mathrm{H}_{7} \mathrm{O}_{2} \mathrm{Na}\right)$ derived from butyric acid has been studied because it acts reducing gastric $\mathrm{pH}$ and dietary buffering capacity, which stimulates the production of pancreatic secretions and reduces colonization by pathogenic microorganisms, both in feed and in the gastrointestinal tracts of animals (KNARREBORG et al., 2002).

Another additive used in piglet nutrition is nucleotides, which are intracellular compounds involved in numerous metabolic processes that are essential for cell growth (MATEO et al., 2004). Nucleotides are precursors of deoxyribonucleic acid (DNA) and ribonucleic acid (RNA), which are key sources of energy, especially in the form of ATP. The benefits of nucleotide supplementation may be related to improvements in histological features and organ morphometry (ANDRADE et al., 2011). Furthermore, dietary nucleotides benefit gastrointestinal morphology and function, the immune system and the intestinal microbiota of monogastric species (SAUER et al., 2011).

However, results describing the true effects of these additives on pig development remain inconsistent. Moreover, determining the effect of combinations of the additives tested in this study and the appropriate concentrations for piglets may contribute to the search for alternatives to antibiotic use as a growth promoter in pig production. The aim of the present study was to evaluate a combination of sodium butyrate, plant extracts and nucleotides as a substitute for antibiotic growth promoters on the weaned pig performance, digestive content $\mathrm{pH}$, organ morphometry and intestinal epithelial histology.

\section{MATERIALS AND METHODS}

The experiment was conducted at the Swine Research Station (CES) of the Federal University of Lavras in Lavras, MG. A total of 90 piglets (18 pigs treatment $^{-1}$ ) from 21 to 56 days of age with an average initial weight of $6.35 \pm 0.34 \mathrm{~kg}$ were assigned to five treatments according to a randomized complete block design: Control, diet with no antibiotic; Antibiotic, diet with $40 \mathrm{mg} \mathrm{kg}^{-1}$ of colistin sulfate; Additive, diets with 1000,1500 or $2000 \mathrm{mg} \mathrm{kg}^{-1}$ of a mixture of sodium butyrate + plant extracts + nucleotides. The additive was composed of 5\% plant extracts, including 2\% Glycyrrhiza glabra (sweet root), $1.5 \%$ Rosmarinus officinalis (rosemary) and 1.5\% Peumus boldus (boldo); 32\% sodium butyrate; 3\% nucleotides prepared from Saccharomyces cerevisiae yeast hydrolysis and carrier $(60 \%)$. Three animals were assigned to each pen (two males and one female or two females and one male) and six replicates per treatment were conducted.

The experimental diets (Table 1) were isocaloric and isonitrogenous and were formulated to meet the requirements of piglets in the pre-initial (day 21 to day 35) and initial (day 35 to day 56) phases of the experiment, as recommended by ROSTAGNO et al. (2005). The animals received water and feed $a d$ libitum during the experimental period. To assess the performance variables, the animals were weighed at the beginning of the experiment, at day 28 , at day 35 and at day 56, and feed intake and orts were quantified.

After day 35 of the experiment, one animal per pen was slaughtered. The animal was chosen according to body weight; the animal chosen possessed the closest to the average weight of the three animals in each pen, independent of gender. After slaughter, the abdominal cavity was opened by longitudinal incision and the digestive organs (stomach, jejunum and cecum) were removed to measure the $\mathrm{pH}$ of their respective contents. The empty stomach, liver and cecum were then weighed for morphometric analysis. For the intestinal histology analyses, samples of approximately $3 \mathrm{~cm}$ in length from the duodenum (removed at $15 \mathrm{~cm}$ from the pyloric sphincter) and the jejunum (removed at $1.5 \mathrm{~m}$ from the ileocecal junction) were washed with saline solution $(\mathrm{NaCl} 0.9 \%)$ and fixed in buffered formalin $(10.0 \%)$ (OETTING et al., 2006; ANDRADE et al., 2011). Subsequently, 
Table 1 - Percent composition and calculated values of basal diets.

\begin{tabular}{|c|c|c|}
\hline Ingredients (\%) & $\begin{array}{l}\text { Pre-initial diet } \\
\text { (day } 21 \text { to day } 35 \text { ) }\end{array}$ & $\begin{array}{c}\text { Initial diet } \\
\text { (day } 35 \text { to day } 56)\end{array}$ \\
\hline Corn & 48.88 & 52.35 \\
\hline Soybean meal (46\%) & 27.10 & 21.94 \\
\hline Milk replacement $^{1}$ & 15.27 & 5.60 \\
\hline Micronized soybean & 1.57 & 6.86 \\
\hline Soybean oil & 1.11 & 2.56 \\
\hline Sugar & 1.11 & 1.01 \\
\hline L-Lysine $\mathrm{HCl}(78 \%)$ & 0.77 & 0.31 \\
\hline DL-Methionine (99\%) & 0.18 & 0.03 \\
\hline L-Threonine (98.5\%) & 0.37 & 0.07 \\
\hline L-Tryptophan (98\%) & 0.08 & 0.02 \\
\hline Dicalcium phosphate & 1.99 & 1.43 \\
\hline Limestone & 0.85 & 0.67 \\
\hline Common salt & 0.41 & 0.35 \\
\hline Vitamin supplement ${ }^{2}$ & 0.05 & 0.05 \\
\hline Mineral supplement ${ }^{3}$ & 0.05 & 0.05 \\
\hline $\begin{array}{l}\text { Kaolin and/or growth } \\
\text { promoter }^{4}\end{array}$ & 0.20 & 6.69 \\
\hline \multicolumn{3}{|l|}{ Calculated values } \\
\hline $\begin{array}{l}\text { Metabolizable energy } \\
(\mathrm{kcal} / \mathrm{kg})\end{array}$ & 3363 & 3270 \\
\hline Crude protein $(\%)$ & 19.76 & 17.92 \\
\hline Calcium (\%) & 0.98 & 0.72 \\
\hline Total phosphorus (\%) & 0.75 & 0.62 \\
\hline Digestible lysine (\%) & 1.52 & 1.08 \\
\hline $\begin{array}{l}\text { Digestible threonine } \\
(\%)\end{array}$ & 0.96 & 0.62 \\
\hline $\begin{array}{l}\text { Digestible tryptophan } \\
(\%)\end{array}$ & 0.26 & 0.18 \\
\hline $\begin{array}{l}\text { Digestible methionine } \\
(\%)\end{array}$ & 0.43 & 0.28 \\
\hline Lactose $(\%)$ & 10.92 & 4.00 \\
\hline
\end{tabular}

${ }^{1}$ Commercial product, Prius L68 - crude protein (10.5\%), lactose $(71.5 \%)$, spray-dried fat $(4.5 \%)$, and metabolizable energy (3780kcal kg-1).

${ }^{2}$ Amount per kg of feed: vit. A - 11,500UI; vit. D3 - 5,850UI; vit. E - 45UI; vit. K3 - 3mg; thiamine - $1.8 \mathrm{mg}$; riboflavin - $5.1 \mathrm{mg}$; pyridoxine - $3.5 \mathrm{mg}$; vit. B12 - $24 \mu \mathrm{g}$; folic acid - 0.82mg; pantothenic acid - 18mg; niacin - 37.5mg; biotin - $0.14 \mathrm{mg}$; selenium - $0.35 \mathrm{mg}$; ethoxyquin $-0.042 \mathrm{mg}$.

${ }^{3}$ Amount per kg of feed: manganese - $60 \mathrm{mg}$; zinc - 150mg; iron $100 \mathrm{mg}$; copper - $10 \mathrm{mg}$; iodine $-1.2 \mathrm{mg}$.

${ }^{4}$ Growth promoter; commercial product.

the tissues were embedded in paraffin and sectioned using a microtome before being mounted on slides in the Histopathology Laboratory of the Department of Veterinary Medicine, State University of Santa Cruz (Universidade Estadual de Santa Cruz - UESC). The villus height (VH) and crypt depth (CD) were measured from images taken with a light microscope and the ratio $\mathrm{VH}: \mathrm{CD}$ was calculated.
The data were subjected to analysis of variance using the PROC GLM of SAS (Statistical Analysis System, 2001). The degrees of freedom of the factor level were broken down into their individual components (linear, quadratic and cubic) using orthogonal polynomials. The following contrasts were also tested using a significance level of 5\%: C1 (Control treatment x Antibiotic treatment); C2 (Control treatment $x$ the mean of 1000,1500 and $2000 \mathrm{mg} \mathrm{kg}^{-1}$ treatments) and $\mathrm{C} 3$ (Antibiotic treatment $\mathrm{x}$ the mean of the 1000,1500 and $2000 \mathrm{mg} \mathrm{kg}^{-1}$ treatments).

\section{RESULTS AND DISCUSSION}

The body weight of the piglets at 21,35 and 56 days of age; average daily feed intake (ADFI); average daily gain (ADG) and feed conversion (FC) were not affected $(\mathrm{P}>0.05)$ by the treatments (Table 2$)$. In the literature, there is no information where herbal extracts, sodium butyrate and nucleotides were added as a compound in the animal feed. This is the first article supplementing piglets feed with a combination of these additives.

The data from this study are consistent with those found by COSTA et al. (2011), who also found no improvement in the performance of piglets (21 to 55 days of age and BW of 6.10 to $20.56 \mathrm{~kg}$ ) that were supplemented with essential oil of thyme (Thymus vulgaris), cinnamon (Cinnamonum zeylanicum), eucalyptus (Eucalyptus urophylla), Melaleuca alternifolia, Echinacea angustifolia, extract of ginger (Zingiber officinale), pepper (Capsicum frutescens) and sodium butyrate which have the same mechanisms of action of the extracts and acids studied in this research. The lack of improvement in the performance of the piglets from the antibiotic or additive treatments in this experiment may be due to rigorous sanitary control of the facilities compared with commercial conditions, which may influence the effects of these additives on animal performance (NRC, 1998; OETTING et al., 2006). Additionally, broilers which have been challenged with Salmonella Enteritidis supplemented with a specific blend of essential oil components and sodium butyrate in the feed, had no beneficial effect on growth performance (CERISUELO et al., 2014).

In the literature, there is great disagreement regarding the effects of plant extracts, organic acids and nucleotides on pig performance (PIVA et al., 2002; WANG \& KIM, 2010). Some studies show results suggesting that the inclusion of such supplements has favorable effects (OETTING et al., 2006; YAN et al., 2012) and others show no effects of supplementation (BHANDARI et al., 2008; COSTA et al., 2011). 
Table 2 - Means of initial live weight (P1), live weight at day 35 (P35), live weight at day 56 (P56), average daily feed intake (ADFI), average daily gain (ADG), and feed conversion (FC) from days 21 to 28, day 21 to day 35, and day 21 to day 56 of age.

\begin{tabular}{|c|c|c|c|c|c|c|c|c|c|}
\hline \multirow{2}{*}{ Variable } & \multicolumn{5}{|c|}{-----------------------------------Treatments ${ }^{1}$----------------------------------- } & \multicolumn{4}{|c|}{-1---------'Contrasts ${ }^{2}$} \\
\hline & Control & Antibiotic & $1000 \mathrm{mg} \mathrm{kg}^{-1}$ & $1500 \mathrm{mg} \mathrm{kg}^{-1}$ & $2000 \mathrm{mg} \mathrm{kg}^{-1}$ & $\mathrm{C} 1$ & $\mathrm{C} 2$ & $\mathrm{C} 3$ & $\mathrm{SE}^{3}$ \\
\hline Initial BW (kg) & 6.36 & 6.35 & 6.35 & 6.35 & 6.36 & - & - & - & - \\
\hline 28 day $\mathrm{BW}(\mathrm{kg})$ & 7.32 & 7.14 & 7.17 & 7.14 & 7.08 & 0.26 & 0.15 & 0.93 & 0.08 \\
\hline 35 day BW $(\mathrm{kg})$ & 9.10 & 8.94 & 8.96 & 9.03 & 8.79 & 0.48 & 0.35 & 0.94 & 0.09 \\
\hline 56 day BW (kg) & 17.19 & 16.76 & 17.31 & 17.49 & 16.69 & 0.58 & 0.53 & 0.97 & 0.23 \\
\hline Days 21 to 28 & 138 & 113 & 118 & 114 & 123 & 0.28 & 0.31 & 0.77 & 0.01 \\
\hline Days 21 to 35 & 196 & 185 & 187 & 192 & 173 & 0.51 & 0.38 & 0.94 & 0.01 \\
\hline Days 21 to 56 & 309 & 294 & 315 & 318 & 285 & 0.50 & 0.52 & 0.82 & 0.01 \\
\hline Days 21 to 28 & 180 & 154 & 163 & 187 & 134 & 0.31 & 0.37 & 0.71 & 0.01 \\
\hline Days 21 to 35 & 318 & 298 & 310 & 318 & 302 & 0.34 & 0.60 & 0.51 & 0.01 \\
\hline Days 21 to 56 & 591 & 544 & 589 & 618 & 542 & 0.30 & 0.30 & 0.86 & 0.01 \\
\hline Days 21 to 28 & 1.37 & 1.37 & 1.59 & 1.71 & 1.18 & 0.99 & 0.56 & 0.57 & 0.08 \\
\hline Days 21 to 35 & 1.63 & 1.63 & 1.68 & 1.66 & 1.77 & 0.96 & 0.35 & 0.31 & 0.03 \\
\hline Days 21 to 56 & 1.92 & 1.82 & 1.87 & 1.94 & 1.93 & 0.30 & 0.22 & 0.96 & 0.03 \\
\hline
\end{tabular}

${ }^{1}$ Control: basal diet; Antibiotic: basal diet with $40 \mathrm{mg} \mathrm{kg}^{-1}$ colistin sulfate; Additive: basal diet with 1000,1500 , or $2000 \mathrm{mg} \mathrm{kg}^{-1}$ of additive. ${ }^{2} \mathrm{C}$ : Control X Antibiotic; C2: Control X mean of 1000, 1500 and 2000mg kg ${ }^{-1}$; C3: Antibiotic X mean of 1000,1500 and $2000 \mathrm{mg} \mathrm{kg}^{-1}$.

${ }^{3}$ Pooled standard error.

Nevertheless, in addition to sanitary control, the different parts of the plants used to obtain the essential oil, the concentrations of the major components (AO et al., 2011), the extraction protocols, the diet composition, the level of dietary added to herbal extracts, sodium butyrate and nucleotides, the different procedures for obtaining and drying of yeast (which containing nucleotides) and possible antagonistic or synergistic effects between additives can influence pig performance.

The $\mathrm{pH}$ of the digestive contents of the piglets was not affected $(\mathrm{P}>0.05)$ by the treatments (Table 3$)$. The current experimental results agree with COSTA et al. (2011), who showed that supplementing piglet feed with plant extracts or organic acids did not affect the $\mathrm{pH}$ of the stomach, jejunal and cecal contents. In contrast, MANZANILLA et al. (2004) found an increase in the $\mathrm{pH}$ of the stomach contents of weanling pigs that were fed formic acid or plant extracts compared with the control treatment. A possible explanation for the lack of change in the $\mathrm{pH}$ of the digestive contents could be the buffering capacity of the feed (COSTA et al., 2011). The basal diet for this experiment consisted of kaolin clay (mineral), protein sources and other sources of minerals, which may have increased the buffering capacity of the feed and prevented $\mathrm{pH}$ variation in the contents of such organs.
The organ morphometry of the piglets was not affected $(\mathrm{P}>0.05)$ by the treatments (Table 3 ). The current experimental results agree with those found by OETTING et al. (2006), who found no difference in the relative weight of the liver, empty stomach and empty cecum while studying the effects of different levels of plant extracts in weanling pig feed. ANDRADE et al. (2011) also found no difference in the morphometry of the stomach, liver and pancreas of weaned piglets while studying the effects of treatment with nucleotides substituted for antibiotics.

In the post-weaning period, there is usually intestinal villous atrophy, given the higher rate of epithelial shedding caused by solid feed intake, the adhesion of pathogenic bacteria to enterocytes and toxin production (OETTING et al., 2006). The positive effects of additives on piglet intestinal histology may be related to the decreased turnover rate of mature cells in the intestinal epithelium, which promotes decreased turnover of enterocytes, thereby maintaining enterocyte integrity. However, in this experiment, the histology of piglet intestinal epithelia was not affected $(\mathrm{P}>0.05)$ by the treatments (Table 3 ). The results of the present study corroborate those found by ABREU et al. (2010), who found no differences in the duodenum and 
Table 3 - pH values of the stomach, jejunal, and cecal contents; mean relative weights (percentage of live weight) of the stomach, liver, and cecum; mean villus height $(\mathrm{VH}, \mu \mathrm{m})$, crypt depth $(\mathrm{CD}, \mu \mathrm{m})$, and the ratio of villus height:crypt depth (VH:CD) in the duodenum and jejunum of the piglets after treatment.

\begin{tabular}{|c|c|c|c|c|c|c|c|c|c|}
\hline \multirow{2}{*}{ Variables } & \multicolumn{5}{|c|}{ 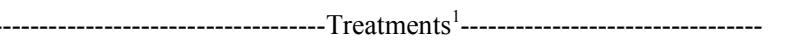 } & \multicolumn{3}{|c|}{----------Contrasts² ---------- } & \multirow{2}{*}{$\mathrm{SE}^{3}$} \\
\hline & Control & Antibiotic & $1000 \mathrm{mg} \mathrm{kg}^{-1}$ & $1500 \mathrm{mg} \mathrm{kg}^{-1}$ & $2000 \mathrm{mg} \mathrm{kg}^{-1}$ & $\mathrm{C} 1$ & $\mathrm{C} 2$ & $\mathrm{C} 3$ & \\
\hline Stomach & 1.34 & 1.58 & 1.77 & 1.54 & 1.34 & 0.52 & 0.92 & 0.50 & 0.12 \\
\hline Jejunum & 6.69 & 6.14 & 6.16 & 6.45 & 6.68 & 0.14 & 0.33 & 0.40 & 0.12 \\
\hline Cecum & 6.10 & 5.98 & 6.28 & 6.09 & 6.08 & 0.58 & 0.35 & 0.77 & 0.07 \\
\hline Empty stomach (\%) & 0.71 & 0.72 & 0.74 & 0.79 & 0.78 & 0.17 & 0.93 & 0.08 & 2.47 \\
\hline Liver (\%) & 2.23 & 2.53 & 2.26 & 2.38 & 2.39 & 0.35 & 0.24 & 0.99 & 8.88 \\
\hline Empty cecum (\%) & 0.21 & 0.22 & 0.21 & 0.19 & 0.22 & 0.21 & 0.76 & 0.07 & 1.01 \\
\hline $\mathrm{VH}(\mu \mathrm{m})$ & 224.72 & 221.24 & 227.27 & 192.49 & 200.27 & 0.48 & 0.16 & 0.56 & 11.80 \\
\hline $\mathrm{CD}(\mu \mathrm{m})$ & 97.48 & 94.50 & 81.20 & 94.72 & 73.09 & 0.86 & 0.40 & 0.29 & 5.14 \\
\hline VH:CD & 2.24 & 2.78 & 2.92 & 2.06 & 2.83 & 0.17 & 0.51 & 0.31 & 0.11 \\
\hline $\mathrm{VH}(\mu \mathrm{m})$ & 201.76 & 197.02 & 223.75 & 178.74 & 209.35 & 0.75 & 0.57 & 0.89 & 5.17 \\
\hline $\mathrm{CD}(\mu \mathrm{m})$ & 87.16 & 83.64 & 95.6 & 79.23 & 83.36 & 0.76 & 0.85 & 0.90 & 3.52 \\
\hline $\mathrm{VH}: \mathrm{CD}$ & 2.47 & 2.43 & 2.40 & 2.29 & 2.60 & 0.91 & 1.00 & 0.88 & 0.09 \\
\hline
\end{tabular}

${ }^{1}$ Control: basal diet; Antibiotic: basal diet with 40 $\mathrm{mg} \mathrm{kg}^{-1}$ colistin sulfate; Additive: basal diet with 1000 ; 1500 , or 2000mg kg-1 of additive. ${ }^{2} \mathrm{C} 1$ : Control X Antimicrobial; C2: Control X mean of 1000, 1500, and 2000 $\mathrm{mg} \mathrm{kg}^{-1}$; C3: Antimicrobial X mean of 1000, 1500, and 2000mg $\mathrm{kg}^{-1}$.

${ }^{3}$ Pooled standard error.

jejunum in $\mathrm{VH}, \mathrm{CD}$ and $\mathrm{VH}: \mathrm{CD}$ while assessing the effects of glutamine, nucleotides, and swine plasma in weaned piglet feed. While studying different concentrations of nucleotides in feed for weaned piglets, ANDRADE et al. (2011) found a linear decrease $(\mathrm{P}<0.01)$ in $\mathrm{CD}$ and a linear increase $(\mathrm{P}<0.01)$ in $\mathrm{VH}: \mathrm{CD}$ in the piglets' duodenums when the levels of nucleotides was increased. According to SAUER et al. (2012), the effect of nucleotides on the morphology of the intestine can vary according to immunological challenges and the conditions of the animals' health.

The sanitary condition of the facilities and low challenge to the animals may be the factors that limit a pronounced effect of the tested additives, as there was no difference between the control and the treatments.

\section{CONCLUSION}

The combination of sodium butyrate $(32 \%)$, plant extracts $(5 \%)$ and nucleotides $(3 \%)$ did not yield improvements in performance or changes in $\mathrm{pH}$ of the digestive contents, morphometry of the organs or histology of the intestinal epithelia of weaned pigs.

\section{ETHICS COMMITTEE ON ANIMAL USE}

The experiment was approved by the Ethics Committee on Animal Use (Comissão de Ética no Uso de Animais - CEUA) of the State University of Santa Cruz (Universidade Estadual de Santa Cruz - UESC), Ilhéus - Bahia, protocol number 029/2009.

\section{ACKNOWLEDGEMENTS}

We acknowledge the "Fundação de Amparo à Pesquisa do Estado da Bahia (FAPESB)" for granting aid for this research - 0040/2010

\section{REFERENCES}

ABREU, M.L.T. et al. Glutamina, nucleotídeos e plasma suíno em rações para leitões desmamados. Revista Brasileira de Zootecnia, v.39, n.3, p.520-525, 2010. Available from: <http:// www.scielo.br/pdf/rbz/v39n3/a10v39n3.pdf>. Accessed: Sept. 20, 2013. doi: 10.1590/S1516-35982010000300010.

ANDRADE, C. et al. Levedura hidrolisada como fonte de nucleotídeos para leitões recém-desmamados. Revista Brasileira 
de Zootecnia, v.40, n.4, p.788-796, 2011. Available from: $<$ http:// www.scielo.br/pdf/rbz/v40n4/12.pdf>. Accessed: Jul. 17, 2013. doi: 10.1590/S1516-35982011000400012.

AO, X. et al. Effects of Saururus chinensis extract supplementation on growth performance, meat quality and slurry noxious gas emission in finishing pigs. Livestock. Science, v.138, n.1, p.187192, 2011. Available from: <http://www.sciencedirect.com/ science/article/pii/S1871141311000114>. Accessed: Jul. 21, 2014. doi: 10.1016/j.livsci.2010.12.029.

BHANDARI, S.K. et al. Evaluation of alternatives to antibiotics

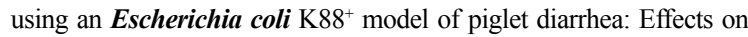
gut microbial ecology. Journal of Animal Science, v.86, n.4, p.836847, 2008. Available from: <http://www.journalofanimalscience.org/ content/86/4/836.full.pdf + html?sid=97644b55-7408-40e7-b15ecbf44d29190f>. Accessed: Jun. 05, 2013. doi:10.2527/jas.2006-822.

CERISUELO, A. et al. The impact of a specific blend of essential oil components and sodium butyrate in feed on growth performance and Salmonella counts in experimentally challenged broilers. Poultry Science, v.93, n.3, p.599-606, 2014. Available from: $<$ http://ps.oxfordjournals.org/content/93/3/599.full.pdf + html $>$. Accessed: Sept. 25, 2014. doi: 10.3382/ps.2013-03528.

COSTA, L.B. et al. Aditivos fitogênicos e butirato de sódio como promotores de crescimento de leitões desmamados. Archivos de Zootecnia, v.60, n.231, p.687-698, 2011. Available from: $<$ http://www.uco.es/organiza/servicios/publica/az/php/img/ web/12 1241 02AditivosCosta.pdf $>$. Accessed: Oct. 09, 2012.

HUYGHEBAERT, G. et al. An update on alternatives to antimicrobial growth promoters for broilers. Veterinary Journal, v.187, n.2, p.182-188, 2011. Available from: <http://www. sciencedirect.com/science/article/pii/S1090023310000869>. Accessed: Jul. 18, 2014. doi: 10.1016/j.tvj1.2010.03.003.

KNARREBORG,A. etal. Establishment and application of an in vitro methodology to study the effects of organic acids on coliform and lactic acid bacteria in the proximal part of the gastrintestinal tract of piglets. Animal Feed Science and Technology, v.99, p.131-140, 2002. Available from: <http://ac.els-cdn.com/S037784010200069X/1s 2.0-S $037784010200069 \mathrm{X}-\mathrm{main} . \mathrm{pdf}$ ? tid=5056b34e31 be-11e3-b5eb-00000aab0 f01\&acdnat $=1381418101$ de48702f9f453e9c24afle7ea40b7098>. Accessed: Ago. 15, 2013. doi 10.1016/S0377-8401(02)00069-x.

LAMBERT, R.J.W. et al. A study of the minimum inhibitory concentration and mode of action of oregano essential oil, thymol and carvacrol. Journal of Applied Microbiology, v.91, n.3 p.453462, 2001. Available from: <http://onlinelibrary.wiley.com/ doi/10.1046/j.1365-2672.2001.01428.x/pdf>. Accessed: Jul. 21, 2014. doi: 10.1046/j.1365-2672.2001.01428.x.

MANZANILLA, E.G. et al. Effect of plant extracts and formic acid on the intestinal equilibrium of early-weaned pigs. Journal of Animal Science, v.82, n.11, p.3210-3218, 2004. Available from: $<$ http://www.journalofanimalscience.org/content/82/11/3210. full.pdf + html?sid=5a739028-917c-4acf-9d5b-f8e1321e6074>. Accessed: Mar. 03, 2013.

MATEO, C.D. et al. Nucleotides in sow colostrum and milk at different stages of lactation. Journal of Animal Science, v.82, n.5, p.1339-1342, 2004. Available from: <http:// www.journalofanimalscience.org/content/82/5/1339.full. pdf + html? sid $=14$ ecaf2d-afc $1-4 a 21$-ae85-316aaf9c6284>. Accessed: Ago. 08, 2013.
NATIONAL RESEARCH COUNCIL [NRC]. Nutrient requirements of swine. 10.ed. Washington: National Academies, 1988. 210p.

OETTING, L.L. et al. Efeitos de extratos vegetais e antimicrobianos sobre a digestibilidade aparente, o desempenho, a morfometria dos órgãos e a histologia intestinal de leitões recém-desmamados. Revista Brasileira de Zootecnia, v.35, n.4, p.1389-1397, 2006. Available from: <http://www.scielo.br/pdf/ rbz/v35n4/19.pdf>. Accessed: Ago 05, 2013. doi: 10.1590/S151635982006000500019 .

PIVA, A. et al. Sodium butyrate improves growth performance of weaned piglets during the first period after weaning. Italian Journal Animal Science, v.1, n.1, p.35-41, 2002. Available from: $<$ http:// www.aspajournal.it/index.php/ijas/article/view/ijas.2002.35/92>. Accessed: Dec. 12, 2013. doi:10.4081/ijas.2002.35.

ROSTAGNO, H.S. et al. Tabelas brasileiras de aves e suínos: composição de alimentos e exigências nutricionais. 2.ed. Viçosa: Universidade Federal de Viçosa, Departamento de Ciência Animal, 2005. 186p.

SAS Statistical Analysis System Institute. SAS user's guide: statistics. Cary. 2001. 155p.

SAUER, $\mathrm{N}$ et al. The role of dietary nucleotides in singlestomached animals. Nutrition Research Reviews, v.24, n.1, p.46-59, 2011. Available from: <http://journals.cambridge.org/ download.php? file=\%2FNRR\%2FNRR24_01\%2FS09544224 10000326a.pdf\&code $=1 \mathrm{a} 9 \mathrm{e} 39 \mathrm{cf} 848 \mathrm{da} 50 \mathrm{a} 454 \mathrm{f} 2789 \mathrm{ffa} 4 \mathrm{ab} 4 \mathrm{~d}>$. Accessed: Jul. 18, 2014. doi: 10.1017/S0954422410000326.

SAUER, N. et al. The effects of pure nucleotides on performance, humoral immunity, gut structure and numbers of intestinal bacteria of newly weaned pigs. Journal of Animal Science, v.90, n.9, p.3126-3134, 2012. Available from: <http://www. journalofanimalscience.org/content/90/9/3126>. Accessed: Dec. 12, 2013. doi: $10.2527 /$ jas.2011-4417.

WANG, J.P.; KIM, I.H. Effects of herbal extracts on growth performance, fecal microbiota, nutrient digestibility, and blood profiles in weaning pigs. Wayamba Journal of Animal Science, v.2, 49-52, 2010. Available from: <http://www.wayambajournal. com/documents/1291802285.pdf>. Accessed: Mar. 17, 2014.

WINDISCH, W. et al. Use of phytogenic products as feed additives for swine and poultry. Journal of Animal Science, v.86, p.E140-E148, 2008. Available from: <http://www. journalofanimalscience.org/content/86/14_suppl/E140.full. pdf + html $>$. Accessed: Mar. 17, 2014. doi: 10.2527/jas.2007-0459.

YAN, L. et al. The effects of dietary Houttuynia cordata and Taraxacum officinale extract powder on growth performance, nutrient digestibility, blood characteristics and meat quality in finishing pigs. Livestock Science, v.141, n.2, p.188-193, 2011. Available from: $<$ http://www.sciencedirect.com/science/article/pii/ S1871141311002058>. Accessed: Jul. 18, 2014. doi: 10.1016/j. livsci.2011.05.017.

YAN, L. et al. Effect of an herb extract mixture on growth performance, nutrient digestibility, blood characteristics, and fecal microbial shedding in weanling pigs. Livestock Science, v.145, n.1, p.189-195, 2012. Available from: <http://www.sciencedirect.com/ science/article/pii/S1871141312000571>. Accessed: Dec. 09, 2012. doi: 10.1016/j.livsci.2012.02.001. 